\title{
Coping with Bank Failures: Some Lessons from the United States and the United Kingdom
}

\author{
R. Alton Gilbert and Geoffrey E. Wood
}

3.

. HE number of U.S. bank lailures has risen damatically in the past few vears. Banks failed at the rate of about six per year from 1950 through 1981 . In 1984, however, 79 banks falled, and 120 banks failed in $1985 .^{\circ}$ yet this sharp rise in the mate of bank failure has not produced the kind of public "panic" that accompa" nied bank failures during much of U.S. history.

In a banking panic, the failure of one bank leads people to fear for the safety of their funds at other banks. Subsequent attempts to withdraw their dem posits from other banks put these banks in jeopardy as well. Recent experience suggests that bank failures no longer cause banking panics. There are now wellestablished and frequently tested principles for preventing a bank failure from tuming into a panic.

To fully appreciate the importance of these principles in preventing panics, it is necessary to review some apisodes of history during which panics occured. History illustrates the inherent vulneability of the banking industry to panics, when there are no policies in place to prevent them; it also illustrates the adverse effects of panics on the operation of banking systems and economic activity.

To prevent banking panics, it is necessary to convince the public that the operation of the banking

R. Alton Gibert is an assistant vice president at the Federal Reserve Bank of St. Lous and Geoffrey E. Wood is a professor of economics at City University, London. Sandra Graham provided research assistance.

A bank is dectared to have failed when it is closed by the government authorities. The government authorities close a bank when its net worth falls close to or below zero. system will not be disrupted by the failure of one bank or even by the failure of several banks. The govemment policies that create this public confidence in the stability of the banking system reflect the history of each nation. This paper contrasts the experience with banking panics in the United Kingdom to that in the United States.

The last banking panic in the United Kingdom ocm curced in 1866 . At that time the Bank of England acted to prevent the disruption of the banking system when banks failed and the public in Fngland came to believe that the Bank of England had accepted that responsibility and would be successful in carying it out.

The United States established a central bank in 1914 . but the Federal Reserve System failed to prevent banking panics in the early 1930s. Thus, the public in the United States did not have the experience of observing a central bank successfully dealing wilh banking panics. The last banking panic in the Inited States (1933) occurred in the same year when the federal government established deposit insurance. This observation inclicates that federal deposit insumance has been an important feature of the policies in the United States for preventing banking panics.

\section{W

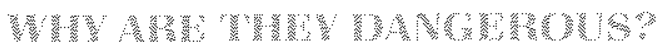

Two features of the operation of commercial banks make the banking system vulnerable to disruptions when depositors lose confidence in their banks. First, 
a large part of the liabilities of banks is payable to depositors on demand. Second, the cast reserves of banks are a small fraction of their deposit liabilities. Thus, if large numbers of depositors suddenly wanted to convert their deposits to currency, the banking system would not immediately have enough cash on hand to honor their demands. When a banking panic occurs, people attempt to be anong the first to convert their deposits to currency because they remember that during previous banking panics, only those who demanded currency eady enough were able to get it."

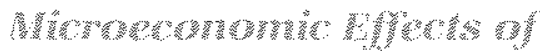

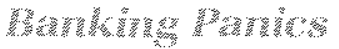

Deposits and reserves of the banking system decline one-for-one as depositors withdraw curency. If total reserves were just equal to required reserves before the withdrawals of curency, resenves would be deficient after the withdrawals. Each bank responds to its reserve shortage by selling assets, producing a decline in demand deposits that exceeds the mitial conversion of demand deposits to currency.

The valnerability of the banking system to panics is illustrated in tables 1 and 2 by the use of balance sheets. Table 1 presents the hypothetical balance sheet of an individual bank that is required by some regulatory authority to keep a cash reserve of at least 10 percent of total deposits. Because of concern about the viability of the bank customers withdraw $\$ 10$ milion in the form of curency, reducing the bank's cash reserves to zero. To raise cash reserves, the bank sells $\$ 9$ million of its interest-earning assets. ${ }^{3}$

When the bank sells its assets to increase its cash reserves, however, it draws cash from other banks, causing their reserves and deposits to decline. These banks must now sell some of their assets to eliminate their reserve deficiencies. Thus, the initial withdrawal of currency by depositors produces a chain reaction of reductions in deposits payable on demand.

The effects on the banking system of the currency withdrawals are llustrated in lable 2 . Prior to the banking panic, the banking system has assets of $\$ 1.1$

\footnotetext{
3Several recent studies develop theoretical models of the behavior of banks and their depositors to investigate the conditions that are likely to cause a banking panic. See Batchelor (1986), Bryant (1980), Diamond and Dybvig (1983), Gorton (1985a), Ho and Saunders (1980), and Jacklin and Bhattacharya (1986).

If many banks sell assets at the same time, the prices of bank assets may fall. In that case, the bank would have to sell additional assets and charge losses against net worth.
}

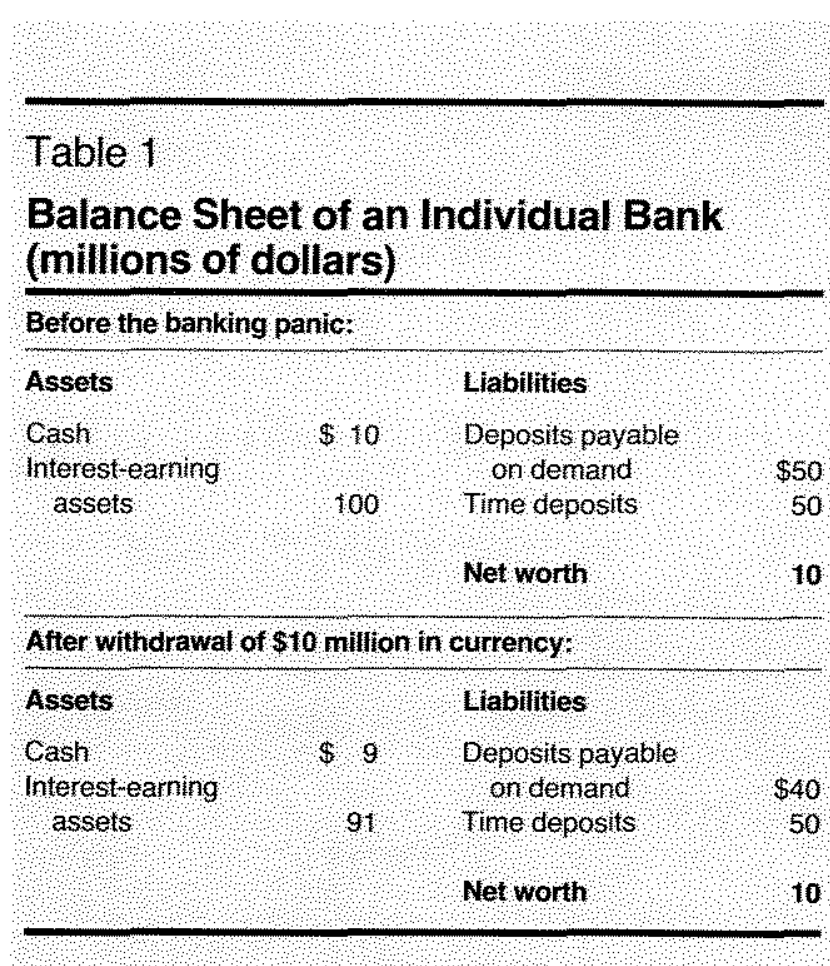

trillion and deposils payable on demand of 8500 billion. As the banking panic begins, bank customers withdraw $\$ 10$ billion in currency from their deposit accounts payable on demand. Given the 10 percent reserve requirement, total deposits must decline until the remaining cash reserves of $\$ 90$ billion are 10 percent of total deposits.

This shrinkage in the assets of the banking system may reduce the confidence of the public in the banking system even more, inducing additional withdrawals of deposits in the form of currency. The addilional loss of reserves would force even larger reductions in bank deposits, interest-earning assets, net worth of banks and number of banks.

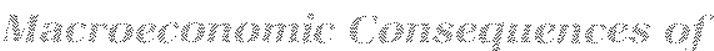

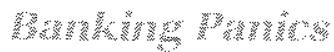

A banking panic causes a sharp reduction in the money supply lcurrency held by the public plus bank deposits payable on demand). Sharp and unexpected reductions in the money supply usually cause reductions in economic activity and, consequently, an increase in unemployment and business fatlures. The panic will end when the public becomes convinced that banks are safe and that it can withdraw currency from deposit accounts whenever it wishes. At that time, the public will again deposit part of its currency with banks. 
Table 2

\section{Balance Sheet of the Banking System (billions of dollars)}

\begin{tabular}{|c|c|c|}
\hline Assets & & Liablities \\
\hline $\begin{array}{l}\text { Cash } \\
\text { Onterestearning } \\
\text { assets }\end{array}$ & $\begin{array}{l}\$ 100 \\
1,000\end{array}$ & $\begin{array}{l}\text { Deposits payable } \\
\text { on demand } \\
\text { Timedeposits } \\
\text { Net worth }\end{array}$ \\
\hline \multicolumn{3}{|c|}{ After withdrawal of $\$ 10$ billion in currency $\$$} \\
\hline Assets & & Liabilites \\
\hline 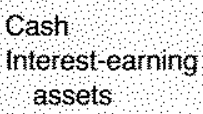 & $\begin{array}{l}\$, 8 \\
8900\end{array}$ & $\begin{array}{l}\text { Deposits payable } \\
\text { on demand } \\
\text { Time deposits }\end{array}$ \\
\hline & & Net worth \\
\hline
\end{tabular}

In the banking panic, sales of interest eaming assets cause the prices of those assets to fall in this ilustration, banks reduce theif net worth by $\$ 10$ billion, recognizing that loss on the sale of assets that had a value of $\$ 100$ billon before the panic

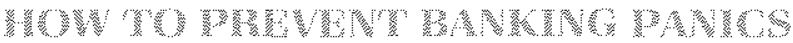

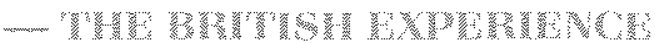

How can the failure of one bank be prevented from spilling over into the whole banking system with such catastrophic consequences? Ony by removing the fear that all banks are in danger of faling. Can this be done in practice? It can, and the way to do it was discovered before the theory behind the method was developed.

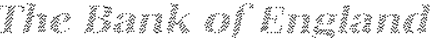

The history of the British approach to preventing banking panics involves the history of the Bank of England. The British govermment chartered the Bank in 1694 as a means of raising funds to fight a war with Fance. Those subseribing to the stock of the Bank made loans to the British government. In return, the Bank was given some exclusive rights to function as a commercial bank. ${ }^{+}$

Although the Bank was privately owned, there was always a close relationship between it and the government. Some aspects of the relationship, based on

\footnotetext{
4Clapham (1944), Fetter (1965) and Santoni (1984).
}

evolving traditions, were implicit ather than spelled out in the Bank's chater or other legislation. for instane, by llee $1800 \mathrm{~s}$, the govemment expected the Bank to buy any part of its new debt issues nol pur. chased by others.

The Bank of England maintained a large inventory of gold upon which it could draw in a panic to meet the public's demand for gold. Legislation in 1844 gave the Bank a monopoy on issuing bank notes and made the notes of the Bank legal tender. That legislation set a limit on the amount of the Bank's notes that could be outstanding, though it specifed that the limit could be exceeded in an emergency. The limit on the notes of the Bank could be lifted at the discretion of the government. Thus, the Bank of England could expand the monetary base (currency plus leserves) in an emergency, since its notes were used as cumency and were held as part of bank reserves.

One aspect of the policies that evolved over time was the Bank's response to a banking panic. The evolution of that policy is described in this section by discussing first, what happened during two banking panics that occured in England during the 1800 s and second, why no panics have occurred in the British banking system since 1866 .

\section{There}

In December 1825, a banking panic occumed in London after the faibue of a bank isir Peter Pole and Companyt. As people fled from deposits al olher banks to gold, gold reserves were drained from the Batkk of England. To convince people that their bank deposits were safe, the bank lent gold freely fom its holdings."

The panic was allayed when it became clear to the public that there was nothing about which to panicthat there was indeed sufficient gold to meet the public's increased demand for gold. As a result, the failure of one bank did not turn into a general financial crisis. Unfortunately, however, banking panics continLed to occur in England after 1825 because the Bank of England had not made a public commitment to act as

\footnotetext{
${ }^{5}$ The actions of the Bank in the panic of 1825 are described vividiy by Jeremiah Harman, diector of the Bank, in Bagehot (1978), p. 73:

We lent if fgold) , , by every possible means and in modes we had never adopted before; we took it stock on security, we purchased exchequer bills, we made advances on exchequer bilis, we fot only discounted outright, but we made advances on the deposit of bills of exclatige to an immense amount, in shot, by every possible means consistent with the safety of the Bank and we were not on some occasions over nice. Seeing the dreadful state in which the pubtic were, we rendered every assistance in our power.
} 
the "lender of last resort" in all financial crises. A lender of last resort acts to increase the monetary base if many people want to withdraw cash gold and notes of the Bank of England from their banks.

The significance of a lendet of last resont in a banking panic car be illustrated by referring to the balance sheets in lable 2. If depositors withdraw cash, the lender of last resort acts to increase the reseaves of the banking system, thus preventing the contraction of the money supply that could be caused by a banking panic. Until the English public became convinced that the Bank of Fngland would act to increase the monetary base lcash in the hands of the public plus bank reserves in financial crises, many of them tended to withdraw cash from banks when there were problems in the financial system.

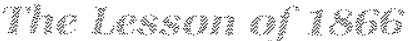

The last major banking panic in England occurred in 1866. Since then, although events have occurred that could have triggered banking crises in 1873,1890 , $1907,1914,1931$ and 1973), they did not do so." What changed after 1866 ?

The panic of 1866 began with the failure of a major English bank. Overend, Gurney and Company was a large bank, founded early in the 19 th century from the amalgamation of two banks that had been important and active in the 18 th century. Hit by a vartety of setbacks, Overend's was compelled to seek assistance from the Bank of England on May 10, 1866. The Bank refused to provide assistance and that afternoon Overend, Gurney and Company was declared insolvent.

The next day, there were runs on all banks. People scrambled for cash because no bank was trusted. The Bank of England, which was being drained of notes, briefly made things worse by hesitating over whether to make its usual purchases of newly issued government debt. By the evening of Friday, May 11, however, the Bank gave assurance that it would provide support to the banking system, and, though demands for small bills continued for a week, the panic was essentially broken in one day." The important consequence of this episode was that the Bank had implicitly accepted

\footnotetext{
${ }^{6}$ A succinct Survey of the history of these episodes can be found in Schwartz (1986).

"Panic, true panic, came with unexpected violence that day." (Clapham, 1944), p. 263. "Terror and anxiety took possession of men's minds for that and the whole of the succeeding day." (Bankers Magazine, 1866). "No one knew who was sound and who was unsound." (The Economist, 1866).

${ }^{8}$ A detailed description of the failure of Overend, Gurney, and Company and the events surrounding that failure can be found in Batchelor (1986).
}

the responsibility of acting as lender of last resort and the public understood that the Bank had accepted that fesponsibility. For a discussion of the historical development of the concept of a lender of last resort, see the insert on the opposite page.

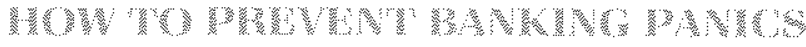 - - w}

The U.S. economy suffered the effects of banking panics long after the British discovered how to prevent them. The United States established the Federal Roserve as the centrat bank in 1914. There were eight major banking panics before then and additional financial crises that had more limited regional inpact." The formation of the Federal Reserve, however, did not end the problem of banking panics; the last panic occurred in 1933. The period since the last banking panic coincides with the period of federal deposit insuranee.

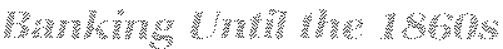

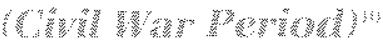

Bank Structure and Regulation - After the Revolutionary War, the new U.S. government confined its monetary role to the minting of gold and silver coin. State governments assumed responsibility for chartering and supenvising commercial banks. State banks issued bank notes, which circulated as currency, and had deposit liabilities against which customers could write checks. Both the bank notes and demand deposits were payable on demand in the form of the coins minted by the federal government.

The frst banking panic occurred in 1814 during the War of 1812 with the British. In response to fears about the outcome of the war, many people attempted to redeem bank notes and convert their bank deposits into coin. The banking system responded by suspending coin payments, which kept the contractions of the money supply and bank assets from being as large as they would have been (see the insert on page 10). In all of the major U.S. banking panics through 1907, the banking system suspended cash payments to depositors and holders of bank notes.

The Panic of 1837 - The panic described above was unusual in that it was triggered by anxieties about the war. Other banking panics in this period occurred

\footnotetext{
${ }^{9}$ The nine major banking panics occurred in 18 $14,1837,1857,1861$, $1873,1884,1893,1907$ and $1931-33$

10 This section is based targely on Hammond (1963).
} 


\section{The Lender of Last Resort and Walter Bagehot}

The name and the work of Walter Bagehot recur continually in the discussion of banking and bank failures, ${ }^{i}$ His main proposal called for the Bank of England to announce that it was willing to act as lender of last resort and that it would do so inhesitatingly whenever necessary. By lender of last resort, he meant that the Bank would, in times of panic, "lend freely, at high interest rates." It would lend freely, so that banks could satisfy the demands of their customers for cash and thus allay panic. It would do so at penally high interest rates to ensure that the Bank was truly the lender of last resort, banks would come to it only when the whole banking system was short of cash. The policy of setting a high lending rate was designed both to prevent excessive monetary expansion in normal times and to guarantee that banks repaid their borrowings when interest rates dropped after the panic, so that the money stock was not permanently boosted by crisis borrowing.

Bagehot was, among other things, a jounalist He became edito of The Economist, and wrote voluminously on many subjects (including The British Constitution). But he is most widely renembered and discussed tor his book, Lombard Street (first published in 1873) (Bagehot, 1978), and for his campaigh in the foonomist to have adopted his recommendations for the conduct of the Bank of England.

when bank failures caused the public to lose confidence in the value of their bank notes and deposits. The panic of 1837 shows the nature of panics in this period before the U.S. Civil War.

The U.S economy experienced an economic boom from 1834 through 1836, supported by large investments in the United States by Europeans. Many of these large investments were in railroads and purchases of public land by those moving to the western frontier

The boom stopped in 1837. Gold flowed from the United States to Europe as European investors demanded payment of their loans and liquidated their U.S. investments. This outflow of gold reduced the cash reserves of banks, which, along with failures by business firms, caused some banks to fail. The Dry Dock Bank, a major bank in New York City, closed on
Bagehot emphasized that the Bank should not only behave in this way, but also should announce in advance that it would do so whenever necessary. He saw this "precommitment," which the Bank had never made before the episode of 1866 , as vital. A credible precommitment would give assurance that sound banks would not be allowed to fail as a result of the failure of some other bank. Once this assurance was given, panic would be less likely. Indeed, the Bank might not actually have to act as lender of last resort at all merely standing ready to do so might be sufficient to provide stability

Although now traditional, Bagehot's recommendation was not accepted without demur Thomson Hankey, a drector of the Bank, was particularly critical of the proposal After the overend and Gurney aftair, Hankey denied that the Bank had an unequivo cal duty to lend freely in parics. He was concerned with what has become known as moral hazard. It bankers know that the central bank will lend freely in a panic, he argued, they will take. more chances hold lower reserves, make riskier loans or pay higher dividends:

Hankey is plainly correct The issue, however, is which is the lesser evil, slightly riskier banks or the prospect of a collapse in the money stock

Hankey s criticism of Bagehot's principles for running a central bank did not represent the official views of the Bank Officially the Bank neither accepted nor rejected Bagehot's principles but came to act in a manner consistent with these principles.
May 8, 1837. All other banks in New York City experienced runs by depositors the next day. The New York Cily banks suspended coin payments on May 10, and Philadelphia banks followed suit on May 11. Within the next 10 days, banks in all the leading cities suspended coin payments.

New Yokk City banks resumed coin payments to holders of bank notes and deposits on May 10, 1838, exactly one year after the suspension. Banks in the rest of the nation resumed coin payments between August 1838 and early 1839

This episode illustrates the vulnerability of the banking system to dismption. Without a central bank, the supply of cash in the economy was determined by the coins minted by the federal govemment and international movements of precious metals. The bank runs following the faiture of the Dry Dock Bank 


\section{Suspending Cash Payments}

Commercial banks in the najor urban areas in the United states suspended payments of cash to depositors and noto holders duing each of the major banlang panies from 1814 hrough 1907 bur ing suspensions, banks in an area would agree to act together in refusing 10 pay out cash Until the 1860s, the form of eash demanded by depositors during panics was metal coins, ht the eany 1860 s, the eash demand duming panics included ourtency

Duning these general suspensions of cash payments banks remained open for business and per mitred their customens 10 use deposits to hake payments to others. Checks were cleared and depostt labilities were transferred among banks Nonredeemed bank notes continued to criculate as camency When banking panies were over banks resumed the payment on demand of con for bank notes and deposits.

The significance of the suspension of bank pay. ments hn the form of con or cumency can be illustrated by refeming to table 2, the balance sheet of the banking system As soon as bankers reallzed that the public was attempting to convelt its money holdings to coin or cumenoy, the bankens as a group refused to meet this demand for cash In this case, their eash nesenves would stay at 5100 billion, and with that cash avallable to meet hesente require ments, the banking systen would not lave to sell assets and reduce its habilities. By suspending cash payments, the banks would prevent the contraction of the assets and liabilities of the banking system showed that the public's confidence in banks could be undermined quickly when an important bank went under. At this time, however, the U.S. banking system had no institution comparable to the Bank of England, which had a reputation for financial strength and an inventory of cash that could cut short a panic. Consequently, some banking panics in the United States, like the panic of 1837 , were followed by long periods of suspended cash payments.

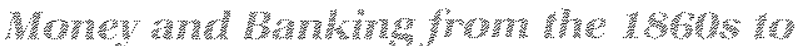

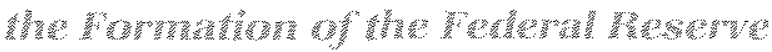

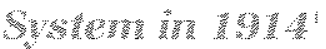

The National Banking System - Reforms were begun in the 1860 s to achieve two purposes: to establish a national currency, with all currency accepted at par value in exchange throughout the nation, and to make the banking system less vulnemble to panics. As a first step, the federal govemment began chartering national banks whose notes were to be the primary national currency. National banks were required to hold both collateral with the Treasury Department against their notes as well as cash reserves that were a percentage of their deposit liabilities and notes. The collateral and reserve requirements were imposed to

This section is based largely on Cagan (1963), Aobertson (1964), pp. 302-30, Scroggs (1924), and Sprague (1910). restrain the growth of bank liabilities and to promote greater public confidence in the banking system.

The basic flaw in the design of the new systern was the absence of a central bank with the power to increase the monetary base should the public lose con" fidence in the value of bank deposits. In this period, there were majos banking panics in 1873, 1884, 1893 and 1907 . Banks acted cooperatively during these panics 10 increase their reserves by creating clearing house loan certificates see the insert on the opposite page). The creation of clearing house loan certificates, however, did not permit banks to meet the public demand for currency. During each of these panics they also stuspended payments of coin and currency to depositors.

The Panic of 1907 The nature of banking panics in this period can be illustrated by the panic of 1907 which occurred in October and November of that year This panic is interesting for several reasons. Its effects on the nonfinancial sectors of the economy were relatively severe, and its events provide a good illustration of how the loss of public confidence in one bank can lead to loss of confidence in the banking system. Finaly, political reaction to this panic led to the for mation of the Federal Reserve System.

For several years prior to $190 \%$, gold flowed from Furope to the United States because Luropeans invested heavily in the U.S. economy. In the fall of 1906 


\section{Increasing the Monetary Base by Creating Clearinghouse Loan Certificates}

The banking system at tempted to cope with the banking panics through energency actions other than the suspension of cash payments. One approach involved the issuance of clearinghouse loan certificates Clearinghouses were cooperative institutions established by banks to economze on the resources used in clearing checks and notes anong themselves, Checks and notes drawn on other members of a clearinghouse were presented to the clearinghouse for collection, rather than being sent to each bank foi collection Banks deposited cash with then deamghouses and in turn, received oes tifcates that were accepted by the other banks for coveming net debit posifions in clearinghouse settlements Orighally, the clearnghouse centificates were menely receipts for cash held by dearmg houses.

In each of the banking panics from 1857 throtigh 1907, the banking system acted eooperatively to expand the monetary base by horeasmg the amount of cleaninghouse certificates outstanding. The certificates issued during the panies were not simply receipts for eash held by the cleanghouses but were loans 10 banks with their assets pledged as collateral The standard practice was for a clearing house association to accept some of the assets of a bank as collateral and issue certificates payable by the clearinghouse association. $A$ bank that weceived such certificates would pay interest on them until they were redeemed after the panic was over These tansactions effectively converted the olearing houses into fractional veserve banking institutions by creating certificates that exceeded their holdings of eash.

Initialy, clearinghouse certificates circulated only among banks that were nembers of the clear inghouse, During panics, clearinghouse members agreed to accept these centifeates in payment from other nember banks, rather than ansisting on payment in cash. The circulation of these certificates ameng banks in place of cash payments allowed he panticipating banks to use thein cash to meet hhe cash demands of their depositors in some panics, however, clearinghouse as octations issued certifcates in small denominations that banks offered to thein depositors as substitutes for cash, These simall-denomination certificates then circulated as currency This use of clearmghouse centificates was not legal but the govennment banking authorities did not chatlenge their use during panics?

Gorton $(1985 \mathrm{a}, \mathrm{b})$ and Timberlake $(1984)$. The Aldrich Vreeland Act of 1908 established a procedure for the emergency is suance of national bank rotes that was copied after the procedures that banks had used for is suing clearinghouse loan certificates durng panics. The panic of 1914 tested the effectiveness of this innovation just before the Federal Feserve System began operations. By issuing notes that were avaltable for such an emergency, banks did not have to suspend cash payments see Cagan (1963) pp $26-28$, and Sprague $(1915)$.
European investors began liquidating their U.S. investments, restilting in large gold oufflows from the United States. This disinvestment was associated with shapp drops in U.S. stock prices in March and August 1907. The U.S. economy went into a recession after May 1907; the rate of decline in real economic activity was relatively low until the banking panic in the fall of that year, but relatively rapid after the panic.

The Panic of 1907 began with a depositor run on the Mercantile National Bank in New York City, which had suffered large losses. The New York clearinghouse came to the aid of the Mercantile National Bank in October 1907, after the bank was put under new management. This action, however, was insufficient to stem the panic. Depositor rums began at other institutions, reflecting a general loss of public confidence in the stability of the banking system. Within a few days, all depository institutions in New York City faced depositor runs. Banks in New York City suspended cash payments in November 1907, and the suspension of payments spread quickly to other cities. The panic and suspension of payments ended in early 1908, but only after a shap decline in economic activity and a 
rise in bankruptcies in the nonfinancial sectors of the economy.

\section{Pon

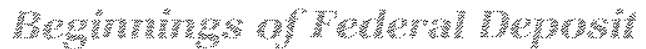 \\ Y}

After the long series of banking panics, culminating in the Panic of 1907, Congress finally responded by passing legislation in 1913 to establish the Federat Reserve System. There were no banking panics from 1914, when the Federal Reserve System began its operations, until the early $1930 \mathrm{~s}$. Then, however, a series of banking crises resulted in the closing of all banks in the nation in March 1933.

The Federal Reserve did not respond to these banking crises as the Bank of England had nearly 70 years before. U.S. commercial banks came under liquidity pressures because of cash withdrawals by depositors and outflows of gold from the United States. Yet, except for a few months in 1932, the Federal Reserve did not increase the monetary base in response to these cash withdrawals from banks. Moreover, commercial banks did not act cooperatively to suspend cash pay ments to depositors as they had in earlier banking crises." Consequently, the deposit liabilities of the banking system declined sharply.

Congress took various approaches to dealing with the general collapse of the banking system in the 1930 s. The most significant legislation was the establishment of federal deposit insurance. There have been no general banking panics in the United States since 1933 .

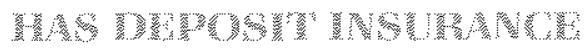

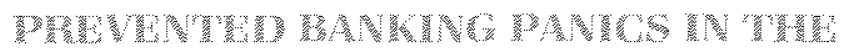

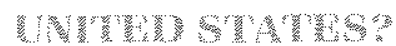

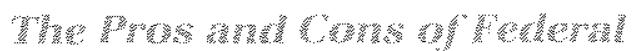

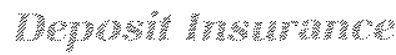

Recent experience indicates that large numbers of bank failures do not induce nationwide banking panics. A controversial issue, however, is whether federal deposit insurance could be eliminated without undermining public confidence in the banking system.

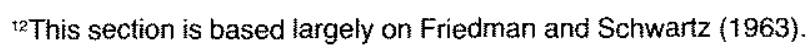

13Friedman and Schwartz (1963, pp. 311-12) argue that banks did not suspend cash payments because they thought the need to do so had been eliminated by the establishment of the Federal Reserve.
The British solved the problem of banking panics more than 100 years before they adopted a program of deposit insurance administered by the government." Some argue that it is time to eliminate federal deposit insurance in the United States. ${ }^{.5}$ In their view, banking panics are best prevented by a credible lender of last resort, and they argue that the Federal Reserve has learned how to function as such. Federal deposit insurance gives depository institutions the incentive to assume greater risk than if deposit insurance were eliminated or offered by private firms.

An opposing view is that federal deposit insurance is essential for preventing banking panics. Since federal deposit insulance has been in effect for over 50 years, depositors rely on it, rather than on their assessment of the financial condition of their banks. In this view, banks would be vulnerable to runs by depositors as they had been prior to 1933 if federal deposit insurance were cancelled.

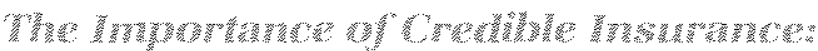

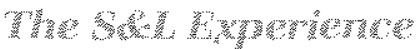

Developments in Ohio and Maryland in 1985 provide some evidence on the importance of federal deposit insurance in preventing banking panics in the United States. The deposits of 80 Ohio savings and loan associations ( $\$ \&$.Ls) had been insured by the Ohio Depository Guamantee Fund (ODGF), a private deposit insurance fund founded by the S\&Ls themselves to insure their deposits. On March 4, 1985, the largest S\&L insured by the ODGF incurred losses because of the failure of a government securities dealer with which the Sol had lage investments. These losses exceeded the capital of the S\&L and the entire reserves of the ODGF. When these events were publicized, depositors at other ODGF-insured Skls began to withdinw their deposits. Theit confidence in the safety of their funds was destroyed when the reserves of the ODGF were wiped out "ir Eleven davs later, the govemor ondered all of the S\&Ls insured by the oDGF closed. One of the conditions for feopening was that

\footnotetext{
14 The Britjsh program of deposit insurance was introduced under the Banking Act of 1979. With few exceptions, all depository institutions are covered and must contribute to an insurance fund. Coverage is 75 percent of each account, with a maxmum compensation of $\$ 10,000$ for each depositor. This program was introduced in response to the secondary banking crisis of the early $1970 \mathrm{~s}$.

${ }^{15}$ Ely (1985), England (1985), ODriscoll and Short (1984), Short and O'Driscoll (1983), and Wells and Scruggs (1986).

16Federal Reserve Bank of Cleveland (1985)
} 
they obtain federal insuranee for their deposits."

The loss of confidence in the ODGF-insured institutions did not lead to a general loss of confidence in depository institutions. There were no tuns on federally insured banks or S\&ls in Ohio.

Similar events transpired in Maryland in May 1985. A private fund insured the deposits of 102 Mayland S\&.Ls. Losses at the largest $\$ \& L$ insured by the private fund triggered runs by depositors on the privately insured S\&Ls throughout the state, Once again, there were no runs on federally insured institutions. The Maryland state government required the privately insured S\&Ls to obtain federal deposit insumance. In reaction to these developments in Ohio and Maryland several other states have required their privately insured thrift institutions to obtain federal deposit insurance coverage.

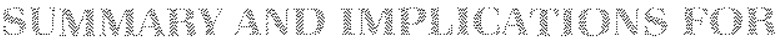 "}

The rate of bank failure in the United States is currently high relative to failure rates in most years since World War II. There have been many episodes in U.S. history when increased bank falures led to banking panics that disrupted the openation of the nation's banking system.

To prevent banking panics, it is essential that the public maintain confidence in the safety of their deposits even though some banks are failing. In the United Kingdom, public confidence in the stability of the banking system was established through the commitment of the Bank of England to act as the lender of last resort in financial crises. This policy was established in the banking panic of 1866 , and the U.K. banking system has not experienced a banking panic since. The basic feature of that policy involves a commitment to increase the monelary base currency held by the public plus bank reserves! when bank runs occur.

Policies in the United States reflect a different histor" ical development. Afer various banking panics, the Federal Reserve was established in 1914 as the central

The Federal Reserve attempted to stop the depositor runs by lending cash to the privately insured S\&Ls. Federal Reserve employees from throughout the System were put on special assign: ment to accept the assets of these S\&LS as collateral tor the cash loans. This response, however, did not stop the depositor funs. This indicates that, in a nation in which cepositors have come to rely on deposit insurance to maintain their confidence in the safety of their funds, the central bank may not be able to maintain that confidence by lending cash to depository institutions when the protection of deposit instrance is suddenly eliminated. bank with the responsibility of acting as the lender of last resort if a banking panic occurred. The federal Reserve failed in that responsibility in the early 1930s, which resulted in a nationwide banking panic in the United states in 1933 . There have been no banking panics in the United States since the federal government established deposit insumance in the 1930s. Runs by depositors on privately insured savings and loan associations in Ohio and Maryland during 1985 provide some evidence that fecteral deposit insurance is an essential feature of the policies in preventing banking panics in the United States.

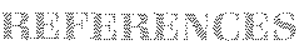

Bagehot, Walter. Lombard Street, reprinted in Norman St. JohnSlevas, ed., The Colfected Works of Walter Bagehot (Hazell Watson and Virey Ltd., 1978).

Bankers Magazine, June 1866, pp. 45-46.

Batchelor, Roy A. "The Avoidance of Catastrophe: Two Nineteenthcentury Banking Crises," in Forrest Capie and Geoffrey E. Wood, eds., Financial Crises and the World Banking System (St. Martin's Press, 1986), pp. 41-73.

Bryant, John. "A Model of Reserves, Bank Runs, and Deposit Insurance," Journal of Banking and Finance (December 1980\}, pp. $335-44$.

Cagan, Phillip. "The First Fifty Years of the National Banking Sys" tem - An Historical Appraisal," in Deane Carson, ed., Banking and Monetary Studies (Fichard D. Irwin, 1963), pp. 15-42.

Clapham, Sir John. The Bank of England: A History (Cambridge University Press, 1944).

Diamond, Douglas W., and Philip H. Dybvig. "Bank Runs, Deposit Insurance, and Liquidity," Journal of Political Economy (June 1983), pp. $401-19$

The Economist, June 1866, pp. 15-16.

Ely, Bert. "Yes - Private Sector Depositor Protection is a Viable Alternative to Federal Deposit Insurance!" in Federal Reserve Bank of Chicago, Proceedings of a Conference on Bank Structure and Competition, held in Chicago, May $\$-3,1985$, pp. 338-53.

England, Catherine. "A Proposal for Introducing Private Deposit insurance," in Federal Reserve Bank of Chicago, Proceedings of a Conference on Bank Structure and Competition, held in Chicago, May 1-3, 1985, pp. 316-37.

Federal Reserve Bank of Cleveland. 1985 Annual Report

Fetter, Frank Whitson. Development of British Monetary Orthodoxy (Harvard University Press, 1965).

Friedman, Milton, and Anna J. Schwartz. A Monetary Histony of the United States, 7867-1960 (Princeton University Press, 1963).

Gorton, Gary. "Bank Suspension of Convertibility," Journal of Monetary Economics (March 1985a).

" "Clearinghouses and the Origin of Central Banking in the United States," The Joumal of Economic History (June 1985b).

Hammond, Bray. "Banking before the Civil War," in Deane Carson, ed, Banking and Monetary Studies (Richard D. Irwin, 1963), pp. 114.

Ho, Thomas, and Anthony Saunders. "A Catastrophe Model of Bank Faiture," The Journal of Finance (December 1980), pp. 1189 207. 
Jacklin, Chartes J, and Supipto Bhattacharya. "Distinguishing Panics and Information-Based Bank Runs: Weifare and Policy Implications," First Boston Working Paper Series 86-16 (February 1986).

ODriscoll, Gerald P., Jr., and Eugenie D. Short. "Safety Net Mechanisms: The Case of International Lending, "Cato Joumal (Spring/ Summer 1984), pp. 185-204.

Robertson, Ross M. History of the American Economy, 2nd ed. (Harcourt, Brace and World, 1964).

Santoni, G. J. "A Private Central Bank: Some Odde English Lessons," this Review (April 1984), pp. 12-22.

Schwartz, Anna J. "Real and Pseudo-financial Crises" in Forrest Capie and Geoffrey E. Wood, eds., Financial Crises and the World Banking System (St. Martin's Press, 1986), pp. 11-31.

Scroggs, William O. A Century of Banking Progress (Doubleday, Page and Company, 1924).
Short, Eugenie D., and Gerald P. O'Driscoll, Jr. "Deregulation and Deposit Insurance," Federal Reserve Bank of Dallas Economic Review (September 1983), pp. 11-22.

Sprague, O. M. W. History of Crises under the National Banking System, National Monetary Commission, Sen. Doc. No. 538, 61 Cong. 2 Sess. (U.S. Government Printing Office, 1910)

"The Crisis of 1914 in the United States," American Economic Review (September 1915), pp. 499-533.

Timberlake, Richard H., Jr. "The Central Banking Role of Clearinghouse Associations" Journal of Money, Credit and Banking (February 1984), pp. 1-15.

Wells, Donald R., and L. S. Scruggs. "Historical Insights into the Deregulation of Money and Banking," Cato Journal (Winter 1986), pp. $899-910$. 